\title{
P53/HDM2 Interaction Inhibitor CGM097
}

National Cancer Institute

\section{Source}

National Cancer Institute. p53/HDM2 Interaction Inhibitor CGM097. NCI Thesaurus.

Code $C 104280$.

An orally bioavailable HDM2 (human homolog of double minute 2) antagonist with potential antineoplastic activity. Upon oral administration, p53/HDM2 interaction inhibitor CGM097 inhibits the binding of the HDM2 protein to the transcriptional activation domain of the tumor suppressor protein p53. By preventing this HDM2-p53 interaction, the proteasome-mediated enzymatic degradation of p53 is inhibited, which may result in the restoration of p53 signaling and, thus, the p53-mediated induction of tumor cell apoptosis. HDM2, a zinc finger nuclear phosphoprotein, is a negative regulator of the p53 pathway, often overexpressed in cancer cells and has been implicated in cancer cell proliferation and survival. 